\title{
The General Theory and monetary policy: Investment versus inflation
}

\author{
Geoff Tily*
}

\begin{abstract}
Keynes's theory of investment and the economic cycle is set out. Against this theory it is argued that the current monetary policy framework is not credible. Rather, given its implicit endorsement of financial liberalisation, it is, and has proved, deeply dangerous. Keynes advocated policies aimed at setting a low long-term rate of interest. Financial liberalisation has led to the dear rates that Keynes understood as the cause of the Great Depression. The discussion also examines Keynes's vigilant approach to inflation and argues that the inflation of the I97os was connected with liberalisation not Keynes. The loss of the central role for investment and the pre-occupation with inflation in post-Keynesian economics is traced. Finally events from the golden age to the present debt-deflation are examined according to this perspective.
\end{abstract}

JEL classification: B22, B50, E40, E60

Keywords: monetary policy, financial liberalisation, investment, inflation, debt deflation

* Government Economics Service, UK. The views expressed here are written in a personal capacity. Thanks to various members of the Post Keynesian Economics Study Group for comments and views, and for organising the symposium and original seminar for which this paper was written. Thanks also to two referees for helpful and challenging comments! The paper was originally written to the remit of the seminar, with emphasis on inflation, but looking too to the high probability of severe recession. I have not greatly changed the paper following the now widespread recognition of the extent of the financial and economic crisis.

Correspondence Address:

Geoff Tily, Head of Analytical Development, GES Team, HM Treasury, I Horseguards Road, London, SWIA 2HQ, e-mail: geoff.tily@hm-treasury.gov.uk.

Received o9 October 2008, accepted: 23 February 2009

C INTERVENTION 6 (I), 2009, 97-II8 
"[W]hilst we intend to prevent inflation at home, we will not accept deflation at the dictate of influences from outside. In other words, we abjure the instruments of bank rate and credit contraction operating through the increase of unemployment as a means of forcing our domestic economy into line with external factors." (Keynes to the House of Lords, May 1943, cited in Kahn 1975: 23)

\section{Introduction}

The growing acceptance that much of Keynes's work was concerned with, or is at least relevant to, monetary policy is a great step forward from previous interpretations. However, the argument of this paper is that recent developments and discussions, including those within post-Keynesian economics, only scratch the surface of the leading role that Keynes perceived for monetary policy.

In a manner somewhat contrary to the remit of this symposium, I argue that the first task for post-Keynesian economics is not to seek credible alternatives to the present consensus, but to see the present consensus as seriously not credible. This lack of credibility follows from an interpretation of new consensus monetary policies in the framework of the General Theory itself.

To do so involves an implicit claim about the nature of Keynes's theory and certain post-Keynesian interpretations: first, that they do not correspond to each other, and second, that Keynes's theory better explains reality. Any such claims challenge the taboo of 'what Keynes really said ‘ and must be controversial. That said, the interpretation here is regarded as rooted most firmly in Chick's work (1983, being the most comprehensive statement), but also as corresponding to the various commentaries on Keynes's theory by Richard Kahn (1984, being his most comprehensive statement). Given most post-Keynesians agree on the poisonous nature of the Keynesian interpretation, a return to the General Theory itself does not seem nonsensical, especially at this precise point in history, when society confronts an economic crisis regarded as on the scale of the Great Depression that partly provoked the work in the first place.

Notwithstanding a measure of demand management, new consensus policies are implemented within a monetary environment and in a manner that Keynes would regard as entirely and 'disastrously « wrong. They are based on setting aside central components of Keynes's theory, in particular the theoretical and practical mechanisms that concerned the rate of interest and fixed capital investment. As Kahn put it:

"Keynes, in his General Theory, writes very little about public expenditure as a means of increasing employment. His main concern was that private investment should be adequately stimulated by low rates of interest « (Kahn I977: 2). ${ }^{1}$

I Recently re-asserted by Peter Clarke in the Financial Times (»In the long run we are all dependent on Keynes", 7 January 2009): "Yet the General Theory had advocated regulating the economy through 
Keynes's monetary policies were aimed at achieving these low rates of interest on both short and long term. In the I930s and 1940s, he oversaw the termination of the post-war order of liberal finance under the gold standard and its replacement with a system that had the management of money under public rather than private authority. Internationally, the IMF was established as a public body to oversee a regime based on managed exchange rates and control of the movement of international capital, as institutionalised in the Bretton Woods Agreement. Domestically, finance ministries and newly nationalised central banks could then use the policy autonomy permitted by the international arrangement to set interest rates across the spectrum.

In summary, I seek to re-iterate the interpretation of Keynes's theory that underpins these policies, examine why it has been lost, and apply it to the question of inflation targeting. Given the focus of the symposium, in the first section the monetary policies that Keynes advocated in his lifetime are briefly examined. Changes in his view are set as the consequence of his changing theoretical perspective (Section 2). By 1930, Keynes had abandoned active management of the discount rate with a view to controlling inflation, and advocated the secular policy of cheap money with a view to stimulating investment, to which Kahn referred. In parallel, he abandoned the long-run equilibrium of classical economics and made the move from the Treatise to the General Theory.

Section 3 sets out the interpretation of the General Theory. Rather than commence with aggregate demand and supply, I depict the theory as emerging from the classical saving-investment equilibrium, which brings investment into the central role. The interpretation then puts on an equal footing the role of the rate of interest, first, in determining the level of aggregate demand and second, in the business cycle process.

The cycle theory requires going beyond the short-period analysis that is normally associated with Keynes's economics, with investment critical to a process that unravels in a longer period. This cycle process indicates a real constraint to economic expansion, but one based on yields of capital, not the labour market. According to my own extension of Keynes's theory, which is rooted in Minsky's work, debt and capital market inflation will be the consequence of excessive expansion under dear money. It is the bursting of these balance sheet inflations that leads to the collapse of expenditure and business expenditure more generally that normally triggers economic recession.

With monetary policy focussed on fostering private investment and neutralising cyclical forces, it was removed from any anti-inflationary role. But it is a travesty to suggest that Keynes's theory and his practical proposals neglected inflationary considerations. His more-than-credible approach to inflation is set out in Section 5, which draws heavily on Kahn's November 1974 lecture »On Re-reading Keynes« (Kahn 1975; from which the quotation at the start of the paper was taken). Adding to Kahn's argument, I contend that postKeynesian economists have not allowed themselves to take seriously the role of monetary factors in the inflation of the I970s.

investment, not consumption, combined with a low and permanent rate of interest«. 
In Section 6, I trace how the matters discussed in this paper have been lost or even discredited in most post-Keynesian analysis. I focus on two aspects: first the dilution of Keynes's theory of investment, through contributions by Shackle and Davidson in particular. Second, I follow how post-Keynesians joined the neo-classics in seeing inflation as inhibitor to employment.

In Section 7, the post-WWII performance of the economy is interpreted according to the broader monetary conditions prevailing. Matters are seen in two eras: in the rgolden age, interest rates were relatively cheap and capital expenditures vigorous and relatively stable. This era surely vindicates Keynes's theory of investment, but it is not seen as such. The world economy has operated under dear money since financial liberalisation in I980. Keynes's theory should lead us to regard this factor - above all others - as responsible for the return of the Economic Problem. If the interpretation of Keynes's cycle theory is correct, present events in financial markets and the real economy reflect the culmination of nearly thirty years of dear money, it is right that these events are now regarded as a matter for very grave concern. The problem is not price inflation, it is debt inflation. Debt inflation leads, or rather has led, to debt deflation. The new consensus on monetary policy has failed.

\section{Early monetary policy and theory}

Keynes's economics began with Indian Currency and Finance (1913). In this and his subsequent contributions up to and including the Treatise on Money (1930), his concern was with inappropriate monetary policies causing economic damage. He saw that discount rate policy aimed at the gold standard exchange parities might be contrary to domestic economic interests. Instead he advocated credit control ${ }^{2}$ using the discount rate - with an eye to inflation - and the deliberate management of foreign exchanges. Such policies of active discount rate manipulation are not greatly out of line with those of the New Consensus, but Keynes abandoned them.

His theoretical worldview was of short-run malfunction against a neo-classical longrun ideal. His Treatise was his first substantial attempt at a theory of the relationship between the operation of an economy in these two perspectives. His central mechanism was based on a development of the classical theory of interest. He argued that saving and investment could diverge: this would then lead to a corresponding divergence between $>$ market and 'natural rates of interest. Keynes appeared to take the latter as a manifestation of the underlying long-run equilibrium of classical economics.

2 The whole of Keynes's economics was underpinned by his recognition of credit creation. The discussion here also has Keynes taking the supply of credit as endogenous in the General Theory, or more specifically as generally responding to accommodate effective demand. While endogenous money might be a cornerstone of their economics, many post-Keynesians - wrongly - do not attribute the notion to Keynes (see Chick (200I) and Tily (2007b), available on request). 
As is well known, the theory was a failure. However, his policy interest became fixed on the long-term rate of interest, rather than the discount rate, as a - if not the - governing factor in the economic situation. ${ }^{3}$ Moreover, the working through of the Treatise was a critical and fast catalyst to the General Theory. In my view, the key step was the abandoning of the saving-investment equilibrium and (hence) the long-run equilibrium of classical economics. ${ }^{4}$

The first evidence of this fundamental shift is in extracts from his November 1932 lectures, published in the Collected Writings:

„On my view, there is no unique long-period position of equilibrium equally valid regardless of the character of the policy of the monetary authority. On the contrary there are a number of such positions corresponding to different policies. Moreover there is no reason to suppose that positions of long-period equilibrium have an inherent tendency or likelihood to be positions of optimum output.« (CWXXIX, 55)

\section{The General Theory}

\section{I The theory of aggregate demand}

The General Theory is dominated by the notion of aggregate demand, with unemployment equilibrium caused by inadequate demand. Most (bastard) ,Keynesians this notion in support of fiscal policy. ${ }^{5}$ But, throughout the General Theory, Keynes had in mind a specific mechanism and model, which did not ordinarily feature government expenditure.

The mechanism had its origins in the classical theory of interest, about which much of the action in the Treatise had revolved. ${ }^{6}$ As he emphasised in discussions prior to publication:

" [T] here is, I am convinced, a fatal flaw in that part of the orthodox reasoning which deals with the theory of what determines the level of effective demand and the volume of aggregate employment; the flaw being largely due to the failure of the classical doctrine to develop a satisfactory theory of the rate of interest." (CWXIII: 489).

3 This position emerges over I930 and I93I, see in particular the discussion at the end of the Treatise (e.g. $C W V I: 377$ ), correspondence with Robert Brand during the course of the drafting of the Macmillan Report, dated 7th April I93I (CWXX: 272-273), and Keynes's Lectures to the Harris Foundation, June I93I (e.g. $C W X I I I: 343-345)$.

4 In Chapter 6 of Tily (2007a), it is argued that this followed his identification of the savinginvestment identity, but this is too simplistic, and a forthcoming paper of the same author examines matters in more detail.

$5 \quad$ Keynes addressed public spending issues in his book, particularly at the end of his discussion of the multiplier (eg. I06, II6 - I22 and I27 - 131), but, in general, he discussed it as supplementary to monetary policy $(164,320,325,335,349,351,376-367$ and 380 ). 
In the General Theory, the classical theory was deconstructed into two (normally) independent parts: first, the theory of liquidity preference and second, the theory of investment demand (Figure I). ${ }^{7}$ The long-term rate of interest was set according to the schedule of liquidity preference (LP) and the supply of money (Figure Ia) in the manner elaborated in Tily (2006). The theory explained how and why policymakers could manipulate expectations and use debt-management policy to set rates of interest across the spectrum. The exogeneity of interest was the key monetary conclusion of the General Theory.

Figure I: The theories of interest (a) and investment (b)

(a)

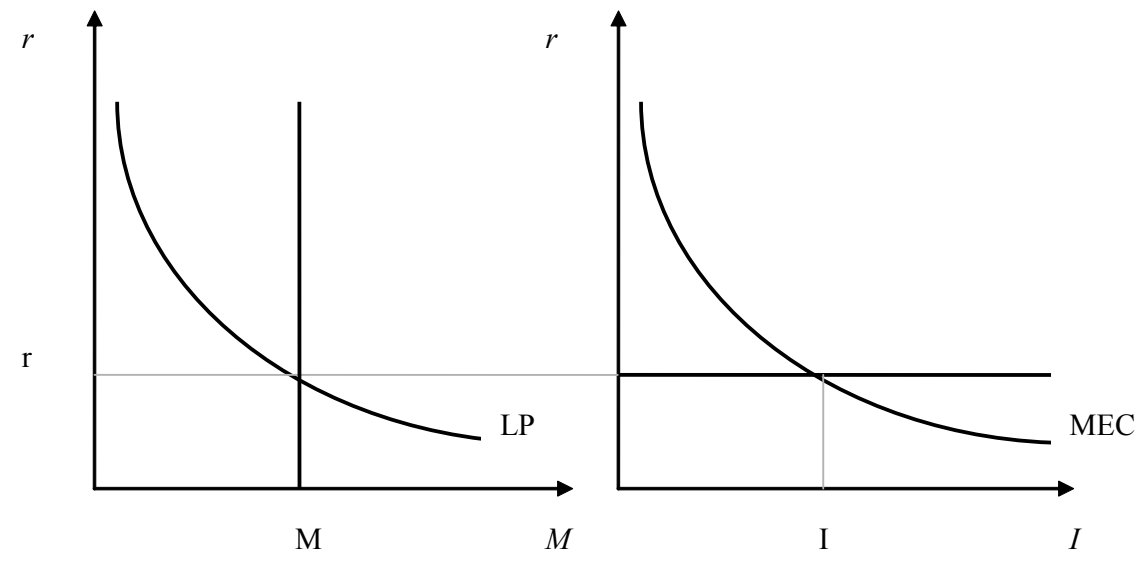

The interest rate then determined the rate of investment according to the schedule of the marginal efficiency of capital (MEC), via a notional supply schedule of finance, perfectly elastic at the prevailing rate of interest (Figure $\mathrm{ib}$; the axes are reversed from the common presentation). Neither the LP nor the MEC schedules is fixed, as in the /Keynesian ‘ bastardisation, but shift according to changing expectations. Nonetheless, on a given MEC, there was a different level of investment for each exogenous rate of interest. Setting a low rate of interest - cheap money - should lead to higher investment.

In the General Theory, as is well known, aggregate output and employment then depended on the multiplier, the marginal propensity to consume and the principle of effective demand. Ultimately the theory explained how a deficiency of demand would lead to unemployment equilibrium. The analysis is necessarily short-period, in an analytical sense. Increased demand would go to employment or prices according to the conditions of supply, with capital fixed.

$7 \quad$ Keynes scarcely used diagrams in any of his work; which can be considered a great mistake, doubly so because the only one he did use in the General Theory was so terribly misleading. 


\subsection{The cycle}

Keynes positioned his cycle theory at the end of the book, Chapter 22: "Notes on the Trade Cycle«. As the title suggests, it was not a substantial account; important points are buried and not elaborated, especially the role of the rate of interest and the notion of a scorrectr MEC. The theory is based on the dynamics of investment demand dictated by ranimal spirits of businessmen, portrayed theoretically as shifts to the schedule of the MEC:

»But I suggest that the essential character of the trade cycle and, especially, the regularity of time-sequence and of duration which justifies us in calling it a cycle, is mainly due to the way in which the marginal efficiency of capital fluctuates. The trade cycle is best regarded, I think, as being occasioned by a cyclical change in the marginal efficiency of capital, though complicated and often aggravated by associated changes in other significant short-period variables of the economic system.« (CWVII: 3I3).

"I suggest that a more typical, and often the predominant, explanation of the crisis is, not primarily a rise in the rate of interest, but a sudden collapse in the marginal efficiency of capital." (CWVII: 3I5).

These passages have no role for the rate of interest: this is introduced shortly afterwards. Without emphasis, Keynes argued "that for each rate of interest there is an amount of investment that is in some sense correct «. This proposition is made most explicitly in the following elaboration of the process:

"It is an essential characteristic of the boom that investments which will in fact yield, say, 2 per cent in conditions of full employment are made in the expectation of a yield of, say, 6 per cent, and are valued accordingly. When the disillusion comes, this expectation is replaced by a contrary error of pessimism, with the result that the investments, which would in fact yield 2 per cent in conditions of full employment, are expected to yield less than nothing [...]. The boom which is destined to end in a slump is caused, therefore, by the combination of a rate of interest, which in a correct state of expectation would be too high for full employment, with a misguided state of expectation which, so long as it lasts, prevents this rate of interest from being in fact deterrent. A boom is a situation in which over-optimism triumphs over a rate of interest which, in a cooler light, would be seen to be excessive." (CWVII: $32 \mathrm{I}-322$, emphasis added).

Here Keynes compared excessiver expectations of the yield of investment with this "correct state of expectation" as a baseline. In terms of the MEC, Keynes appears to be arguing that there is a >correct MEC schedule against which other schedules, assessed in uncertain circumstance and influenced by various degrees of optimism, can be compared. Key aspects of this process are illustrated in Figure 2 on the next page. 
Figure 2: The economic cycle

(a)

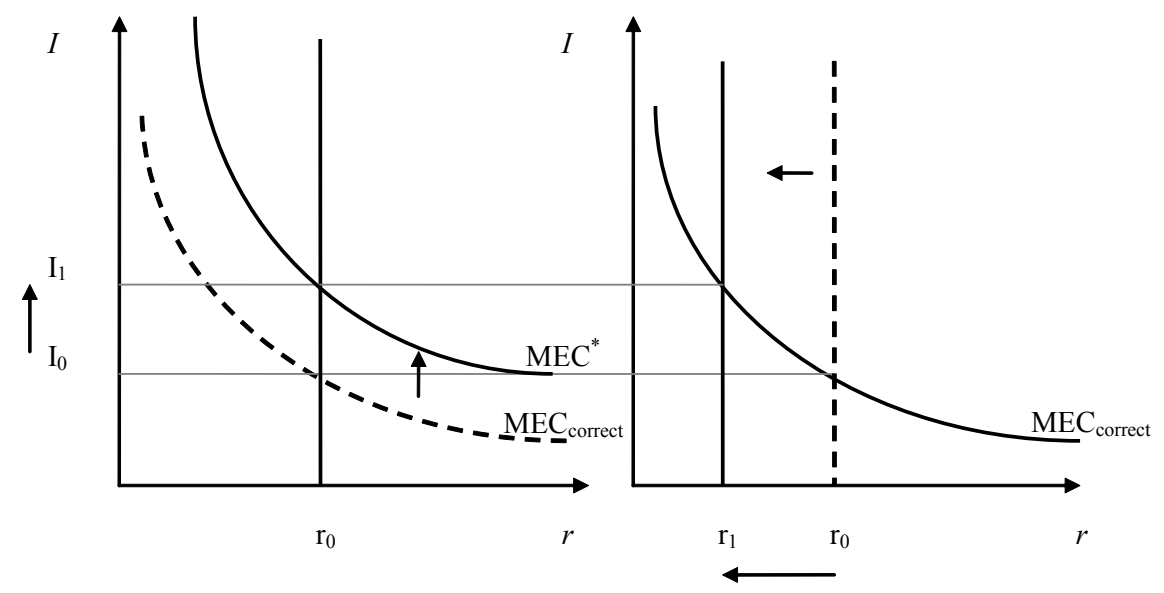

In Figure 2a, the rate of interest, $\mathrm{r}_{0}$, corresponds to a volume of investment, $\mathrm{I}_{0}$, measured on $\mathrm{MEC}_{\text {correct }}$, a notional scorrect $\mathrm{MEC}$ schedule. The expansion phase of the business cycle is then illustrated by a shift to MEC*, the schedule reflecting firms' excessively optimistic assessments of the yields on investment, leading to investment demand of $I_{1}$.

Eventually investment implemented under such conditions will go into reverse: the MEC shifts to the left. This leads to the contraction in investment that defines the recession or `depression` phase of the economic cycle. Keynes's description goes little further. Instead he turns to his terribly straightforward solution:

"The remedy for the boom is not a higher rate of interest but a lower rate of interest. For that may enable the so-called boom to last. The right remedy for the trade cycle is not to be found in abolishing booms and thus keeping us permanently in a semi-slump; but in abolishing slumps and thus keeping us permanently in a quasiboom.« (CWVII: 322).

The cheap-money solution to the economic cycle achieves a high level of investment by $r$ ducing the rate of interest rather than through shifts to the MEC that he regarded as only temporary. This alternative is illustrated in Figure $2 b$, where the higher level of investment (the so-called sbooms), $I_{1}$, is achieved with a reduction in the rate of interest from $r_{0}$ to $r_{1}$.

In Tily (2007a: Chapter 8) the author attempts to develop this process and explain the eventual collapse of the MEC as endogenous to the cycle process. This follows an analysis of the outcome of investment, measured in terms of revenues following the implementation of the new plant. ${ }^{8}$ The analysis is slong-period, examining the consequences of allowing investment to vary, in contrast to short-period analysis where investment is fixed (and

8 It should be noted that some of this discussion was originally written as the investment boom of 
it seems to accord with Chick's (1998) »equilibrium of action«). The key point is that revenue flows will either validate or invalidate the original expectations when the investment was put into place. ${ }^{9}$

In Figure $2 \mathrm{a}$, at the rate of interest $\mathrm{r}_{0}$, investment projects represented by the difference between investment demand and the correct investment, $\mathrm{I}_{1}-\mathrm{I}_{0}$, will, by definition, be such that revenues fail to meet expectations. I argue that in a boom these failures of revenues will greatly damage corporate finances and lead to large-scale distress borrowing; there will be an expansion of corporate liabilities - or debt inflation - counterparted by an asset inflation. Eventually the bubble will burst, and distress financing will dry up. At that point companies will be forced to 'de-leverage, and debt deflation will begin. Actions will involve reductions in costs, curtailment of investment programs, redundancies and declarations of bankruptcy. Unemployment and recession will be the consequence.

\subsection{Keynes's solution revisited}

While a cheap-money policy allows an economy to operate according to a higher level of investment, it does not immediately follow that that investment should be more stable than the equilibrium in the dear-money case. From a theoretical perspective, in a cheap-money economy it is not possible to rule out substantial shifts in the MEC leading again to debt inflations and financial collapse. Keynes did not address this issue in the General Theory. Such developments are perhaps more unlikely in the cheap- than the dear-money case. In particular, excessive expectations should be less likely in an economy already operating at a high level of activity and one where expectations were not distorted through routine policy

the late I990s began to unravel; some of the ideas are therefore drawn from events. The author's wider notion, that investment collapse was imminent, came before that collapse.

9 Strictly, what might be called ivalidation by revenue processes can only be judged over the full duration of an investment. The outturn of the stream of revenues for any marginal investment will then either have met or failed to have met the cost of the finance for putting that investment into place. In practice, however, it is unlikely that businesses can wait until the end of the investment repayment process to appreciate that revenues will not meet costs. Firms' cash flow calculations for the duration of an investment will have assumed a certain profile of returns over time. The extent to which excessive investment is revealed at an early stage will depend on this profile. At the extreme, if all returns are expected in the final period then firms will not know until this period. For most projects it might be reasonable to assume that returns are likely to be linear (with perhaps a positive gradient) across the investment. In these cases, the excessive nature of the investment will be revealed from fairly early on, and firms may encounter cash flow problems according to a similar timing. In the aggregate, it is likely that these types of projects will dominate. To reflect this, >outturn ‘ will not be used in the strict sense of the stream of revenues over the whole life of the investment, but more loosely to reflect a position where an investment has been put into place and is generating revenue. Jumping ahead, it may be that in some cases banks are willing to re-finance loans for as long as they believe that a company's shortfall in revenues is due to incorrectly profiled revenues rather than a miscalculation of total revenues. In the limit, this would mean that re-financing would take place until very late in the life of any investment. 
manipulation of the short-term interest rate (see section 4). Similarly, the consequences of excessive expectations might not be so severe in a cheap-money economy because the cost of any associated debt would be less (and could too be ameliorated by a degree of inflation).

The role of uncertainty and expectation in the economic process means that no watertight conclusions can be drawn. What is certain, though, is that dear money does not prevent easy money, and dear-money policy will be likely to provoke excessive expansion followed by recession. Rejecting cheap money on the grounds that it may make money easy neglects this point that dear money does not prevent easy money and, at the very worst, amounts "to refus[ing] to be cured because that will make it possible to become sick again" (Lerner 1964: 222). Moreover the actual experience of cheap money should not be neglected, see Section 6.

\subsection{Equilibrium and the General Theory}

In Tily (2007a) it is argued that the processes outlined by Keynes might fairly or usefully be regarded as involving "multiple long-period equilibrium«. Hayes's review (2008) suggests this goes too far.

Keynes's theory decisively rejected the notion that labour market considerations governed the underlying or long-run operation of an economy. It broke the equilibrium between investment, saving and the rate of interest. It broke too the additional classical notion that in a market economy the rate of interest adjusts to accommodate any changes in the yield on investment (sometimes known as the rate of profit). Equilibrium in any classical sense is certainly gone.

Yet the author remains concerned to emphasise that the cycle process is underpinned by something real: namely limits to the yields on investment. The notion that there are no limits to demand-driven expansion should be discarded. In Keynes's theory the rate of interest is a monetary phenomenon, which sets an upper bound to investment profits according to their (projected) yields. Nothing in the system ensures that the upper bound is in any sense optimal, in particular that it will correspond to full employment. In this way, the rate of interest defines some sort of an unemployment equilibrium for the system. The trade cycle discussion indicates that neither is this upper bound sbinding in terms of the day-to-day operation of a free market economy. Under the influence of optimistic animal spirits, investment can exceed the upper bound. But the upper bound does exert an underlying force on the system. In particular dear money sets too-high-a threshold for the yield on investment to result in anything like full employment. The system may well expand at an excessive rate; the fundamentals - fairly low unemployment, relatively high growth and low inflation - may appear sound, but Keynes's theory predicts that it is a temporary state of affairs, liable to abrupt reversal.

The author suggests to regard the process as following from long-period analysis, based on underlying yields on investment. Kregel's (1976) notion of shifting equilibrium, may be the most useful for describing the state and dynamics of the economy. However, under 
dear money, at a point defined by financial crisis, there will be an abrupt shift of this equilibrium from relatively low to potentially very high unemployment.

\section{Inflation, discount rate policy and the short period}

With an interest rate policy of cheap money shown to lead to a high level of aggregate activity and to prevent the cycle, Keynes discarded the aiming of monetary policy at inflation. ${ }^{10}$ Clearly, when Keynes wrote the General Theory inflation considerations were not uppermost. Yet it is a travesty, born of years of misinterpretation and prejudice, to suggest that Keynes was negligent when it came to inflation. Kahn (1975) has provided the fullest and most robust defence, and I draw heavily on his discussion in the below.

Unlike bastard Keynesianism, the General Theory included a full theory of inflation (Chapter 2I). Under normal conditions, Keynes expected rises in prices and wages as a consequence of expansion, and then foresaw conditions of true inflation:

"When a further increase in the quantity of effective demand produces no further increase in output and entirely spends itself on an increase in the cost-unit fully proportionate to the increase in effective demand, we have reached a condition which might be appropriately designated as one of true inflation. Up to this point the effect of monetary expansion is entirely a question of degree, and there is no previous point at which we can draw a definite line and declare that conditions of inflation have set in. Every previous increase in the quantity of money is likely, in so far as it increases effective demand, to spend itself partly in increasing the cost-unit and partly in increasing output." (CWVII: 303).

Kahn draws attention to Keynes's various statements to the effect that the world had discarded the weapon of creating unemployment to prevent inflation (see for example the quotation at the start of this paper). Keynes's practical initiatives also reflected an awareness of inflation. He ensured that the increase in floating debt that followed as a consequence of his interest rate policies would not be reservable at the central bank, and therefore prevented an increase in private credit. His How to Pay for the War proposals were at root concerned with the inflationary consequences of operating a war economy. He developed an innovative balance between taxation and government spending to prevent both wartime inflation and post-war deflation. ${ }^{\text {II }}$ These proposals, above all, make Kahn's citing of Harrod's claim concerning Keynes's approach to inflation entirely appropriate:

Io The discount rate was effectively 'parked, in accordance with the term structure of interest rates that the authorities sought to establish.

II This involved significant developments to National Accounts, see Tily (2009). 
"What do we do? What is the remedy? It would be most inappropriate for me to stand up here and tell you what Keynes would have thought. Goodness knows he would have thought of something much cleverer than I can think of." (Kahn I975: 8).

Kahn provides evidence that Keynes considered inflation a political rather than economic problem; perhaps it would be more accurate to describe it as a technical and political problem. Kahn also offered the evidence of a Low cartoon, showing Keynes as barrier (»road closed J.M. Keynes at work«) to runners approaching a road signposted »vicious spiral to inflation", presumably to indicate that the public perception of Keynes was of his robust opposition to inflation, quite the reverse of perceptions subsequently engendered by the profession.

The post-Keynesians' own pre-occupation with inflation follows the mainstream (see next section) and is reflected by the remit of the present symposium. Surprisingly many post-Keynesians are equally unwilling to see in Keynes a very different approach to that of the `Keynesiansı. All of the above considerations are surely relevant, but the experience of inflation in the I970s that has so obsessed economists must surely also be re-assessed in the light of the re-examination of Keynes's policies, especially the extent to which actual policy and behaviour differed from Keynes's ideal. Kahn addressed this in terms of how "Keynes's vision of the post-war world has turned out to have been seriously defective in a number of important respects« (Kahn 1975: 23). He made four main points:

I. the prolonged duration of high aggregate demand;

2. the IMF's inflexibility on exchange rate changes;

3. the higher growth of wages relative to productivity in Britain (more so than in other countries); and

4. the high money cost of production twenty nine years after the war.

To these, the severe misapplication of Keynes's monetary policy should be added. First, the specific domestic and international monetary policies that Keynes advocated at the end of the war were by no means fully implemented (Tily 2006). The measures advocated at the National Debt Enquiry were abandoned within only a few years. The Bretton Woods Agreement was a shadow of his International Clearing Union. Second, when the discount rate was re-activated, it was operated in a stop-go fashion, seemingly related to the electoral cycle. Third, the inflation of the I970s was preceded by a good deal of financial liberalisation, starting in the late I960s, as financial institutions successfully lobbied for greater lending powers. Matters culminated in the Bank of England's Competition and Credit Control (characterised after the event as "all competition and no control «). The increased lending and expansion in demand was of course facilitated by the termination of the Bretton Woods agreement at the start of the i970s.

Figure 3 shows an immense growth in $\mathrm{M}_{4}$ lending from 1966, plainly leading consumer price inflation over this critical period. While $>$ Keynesians might have believed in the immutability of the Phillips relation, commonsense - let alone any sensible interpreta- 
tion of Keynes's analysis - says that such a rapid expansion of credit, even from a low base, must have at least had a role in the inflation of the 1970s. ${ }^{12}$

Figure 3: Inflation and credit

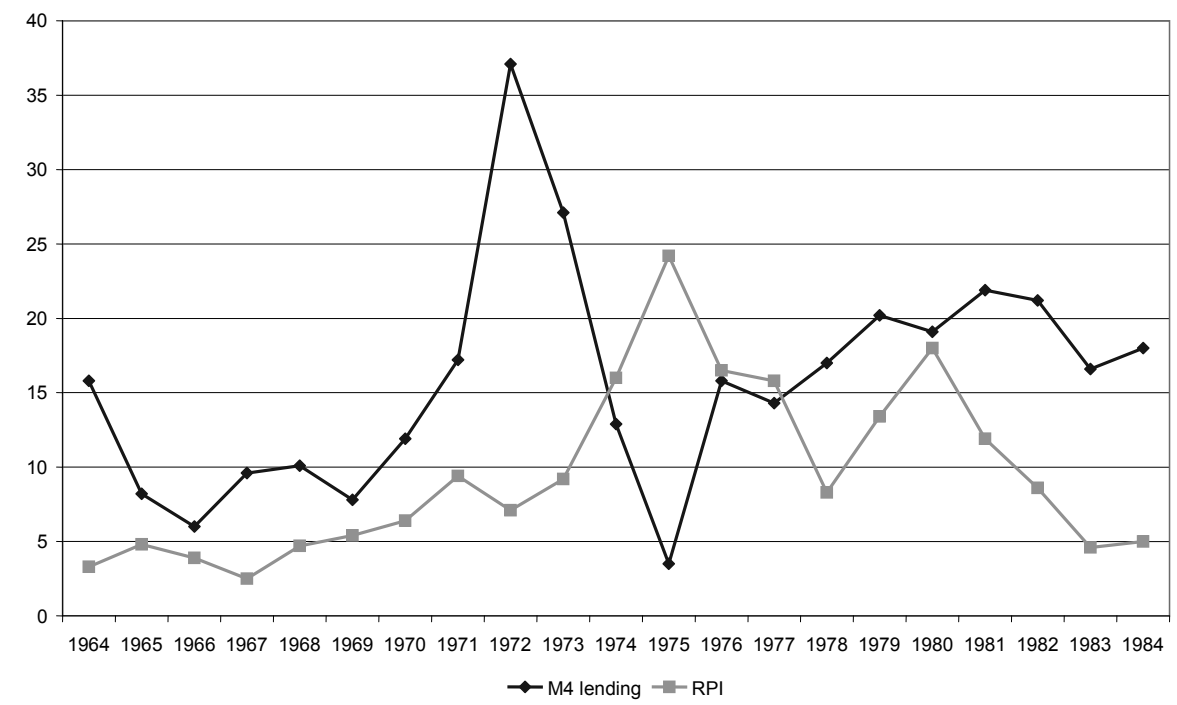

Source: Office for National Statistics; Bank of England

As with much about Keynes, the truth may be the reverse of the popular perception. Keynes was acutely aware of the dangers of inflation and took an innovative approach, the likes of which has not been seen before or since. The I970s inflation that has been identified with his name may well have had more to do with the ending rather than the implementation of his policies. Certainly, for Keynes, a degree of inflation was a likely side-effect of expansion, but was not to be feared. According to his theory, the new consensus policy defeats inflation by causing unemployment, and it is the offspring of a hopeless theory that fails to recognise the more fundamental underlying mechanisms at work in a monetary economy.

\section{Investment and inflation in post-Keynesian economics}

Most culpability for the loss of Keynes's theory and policy rests, of course, with the $>$ Keynesians‘. Yet while post-Keynesian economics has restored much of Keynes's work, it has not restored investment to the central role shown here. While I am anxious that the following

I2 Kaldor's (1972) notion that that there was no limit to expansion, published concurrently with this inflation, must have done no end of damage to the prejudice of Keynes as having neglected inflation (see footnote i9). 
analysis is very brief and will not do justice to those mentioned, validity rests on the unambiguous nature of the statements cited. The contributions belong to the school of postKeynesian economics that gives such great emphasis to uncertainty, almost at the expense of all other mechanisms.

The perspective appears to have its origins in very early mainstream attacks on Keynes. These began with the work of Hubert Henderson's (Keynes's bitter rival) $>$ Oxford Economics Research Group (OERG). In its new journal, Oxford Economic Papers, Henderson (1938) vigorously argued that reductions in the rate of interest would not increase investment. His own agenda was supported by empirical work by James Meade and P. W. S. Andrews (1939).

George Shackle's early contributions drew on the work of the OERG and these merit emphasis because of his close association with the post-Keynesian paradigm. While Shackle championed uncertainty and rejected $I S-L M$, he consistently rejected the rate of interest as a solution to the economic problem.

"Those who read the letter, rather than the spirit, of the General Theory, and even perhaps Lord Keynes himself in the initial stages of his writing, have been tempted to mistake the central position which the rate of interest appears to occupy in the logic and aesthetic of his system for its importance in the real world. Inquiries such as those made (by personal interview and questionnaire) by the Oxford Economists' Research Group in the years before the present war have shown strong evidence that, so far as investment in industrial equipment is concerned, the rate of interest is less potent than orthodox theory, and some interpretations of the Keynesian theory, suggest. The demon who really opens or closes the throttle of economic activity is not the rate of interest, but the marginal efficiency of capital, with everything that this schedule rests upon, that is to say, all the factors which shape expectations, and the sutter doubt‘, precariousness, hope, and fear." (Shackle 1943: 26I) ${ }^{13}$

As the quotation indicates, initially Shackle did not reject the MEC; indeed for him investment was a phenomenon of pure uncertainty. But with the rate of interest ruled out as of no importance, the central theoretical pillar of Keynes's theoretical construct and the foundation for policy was gone. ${ }^{14}$

I3 The assertion that Keynes moved away from cheap money is not evidenced, is unfounded and is wrong. Another good example of Shackle's rejection of the role of interest is in his 1961 survey of interest rate theories, published in the Economic Journal; he concluded: "It seems likely that the interest rate, or the system of rates, will continue to receive from theoreticians the homage due to a ceremonial monarch, without in fact counting for more than such a monarch in the real affairs of western nations" (Shackle 196I: 252).

I4 In a review of The Years of High Theory, Joan Robinson (1968: 186) berated Shackle: „For Shackle, reconomics is about choicer. When Keynes has proved that rational choice is impossible in an uncertain world, he has destroyed the very basis of economic theory (p. 247). But Keynes, after all, pro- 
Later he went further: he removed the MEC from his theoretical scheme and developed instead a supply and demand representation of the "inducement to invest «, utilising a "demand price of equipment rather than the marginal efficiency of capital (Shackle 1965: 88 and $80-89$ ). Paul Davidson's Money and the Real World then canonised this theory of investment as follows:

"Despite the fact that Keynes utilised the concept of the marginal efficiency of capital (which was defined as equal to the rate of discount), it is obvious that Keynes always viewed the production of investment goods in a monetary economy as depending on the comparison of the demand price with the flow-supply price.« (Davidson $1978: 70)^{15}$.

Davidson's supply-demand investment theory does not reject a role for the rate of interest, but refers only to the discount rate rather than the long-term rate and any impact is more indirect, seemingly affecting the demand schedule for investment goods:

"For example, changes in the market rate of interest may affect the demand for capital not only via altering the rate of discount used in capitalising the expected yield, but also by creating new expectations about (a) future sales [...] and (b) future interest rates" (Davidson 1978: 73)

With his theory of investment gone, Keynes's cycle theory is lost. There is no possibility of cyclical action revolving around the rate of interest and the MEC if they have been discarded.

The most important post-Keynesian theory of the cycle is of course Minsky's financial instability hypothesis, to which the present discussion is greatly indebted. Minsky analyses an investment expansion based on excessive optimism and proposes a sustainability criterion based on revenues such that "the profit flows must be sufficient to validate debts" (Minsky 1985: 37). He sets out three financial 'postures on the part of firms as 'hedges, sspeculativer and 'Ponzi finance. The latter is most closely related to the discussion here.

"3. Ponzi< finance. The cash flows from assets in the near term fall short of cash payment commitments and the net income portion of the receipts falls short of the interest portion of the payments. A Ponzi finance unit must increase its outstanding debt in order to meet its financial obligations." (Minsky 1985: 43)

However the rate of interest does not play the same role in Minsky's scheme as in Keynes's. In the Keynes model, under dear money, Ponzi finance becomes endemic. In Minsky's model the role of the interest rate is different, perhaps partly following from the pre-occupations

duced a great effect upon affairs - or, if we like to maintain that post-Keynesian near-full employment would have happened anyway, at least he has made it possible to understand affairs. This is not intellectual nihilism [...]. The theologians nowadays are trying to push economics back from exploring the questions that he opened up«.

I5 Shackle (1973) gave the work a glowing review in the Economic Journal. 
at the time. Minsky has policymakers increasing the discount rate to counter inflation, the increased cost to firms then triggers the debt deflation and recession. ${ }^{16}$

Davidson's basic model features inflationary tendencies as a more general inhibitor to growth, rather than as a trigger of debt deflation. This perspective has maintained a hold on PKE ever since. ${ }^{17}$ Ultimately Davidson has the central bank able to foster activity with the discount rate and the supply of money. But, and citing Keynes from the Treatise (Vol. II: 35I):

"If $₫$ however, there are strong social or political forces causing spontaneous changes in the money-rates of efficiency-wages, the control of the price-level may pass beyond the power of the banking system ‘ [...]. Hence, unless rules of the game are established via the political process to prevent rapid changes in money earnings per unit of effort over time (an incomes policy), modern economies will fluctuate between the Scylla of inflation and the Charybdis of unemployment." (Davidson 1978: 245).

Basil Moore offers a fairly prominent recent statement of the same view. He holds: »The Phillips Curve is alive and well. Wage moderation remains the fundamental prerequisite for price stability« (Moore 2004: 330).

Davidson's perspective on investment, and to some extent inflation, has prevailed through the modern post-Keynesian literature, much of which almost entirely ignores the relation between interest and investment. In a recent symposium, Rochon's introductory contribution categorically dismisses Keynes's investment theory from modern post-Keynesian discourse:

"Now we can reject Keynes's logic on the interest rate - investment link and his contentious use of a marginal efficiency of capital schedule, but we can still promote

I6 Fisher is commonly cited in the context of debt deflation. His central argument was as follows: "I venture the opinion [...] that, in the great booms and depressions, [...] [the] two dominant factors, [...] [are] overindebtedness to start with and deflation following soon after [...] (Fisher 1933: 340-34I). His paper examined a chain of ten events as the debt build-up process was reversed (Fisher 1933: 343). Ultimately, however, he saw matters based on real not monetary causes: "The over-indebtedness hitherto presupposed must have had its starters. It may be started by many causes, of which the most common appears to be new opportunities to invest at a big prospective profit, as compared with ordinary profits and interest, such as through new inventions, new industries, development of new resources, opening of new lands or new markets." (Fisher 1933: 348)

I7 Plainly not all PKs adopted this approach. For example, at around the same time, Kaldor took a position seemingly entirely opposed to Davidson. The title of his `The Irrelevance of Equilibrium Economicsı, says it all. With any equilibrium constraint thrown off, Kaldor's vision was of unconstrained growth: »But if we take an inclusive view, neither labour nor capital can limit either the level, or the rate of growth, of production over a longer period. Capital accumulation can always be speeded up or rather it automatically gets speeded up, with a faster growth of production.« (Kaldor 1972: I25I) As noted, the timing of publication permitted Kaldor a strikingly irresponsible contribution to the notion of, Keynesians as inflationists‘. 
the necessity of low interest rates for other reasons, such as for income distribution." (Rochon 2007: 7).

Commonly Keynes's theories in Chapters I2 and I8 are seen as incompatible, one looking to a world of uncertainty, the other inviting formulation of the theory as neo-classical equations (see for example King 2002: I4). The author does not regard any such justifications for disregarding Keynes's theory as adequate.

However, this perspective is not taken by all post-Keynesians. In particular, Chick's account of the General Theory retains investment in the central role. She also (Chick 1983: I30) explains the difficulty of empirical verification of Keynes's theory of investment, as well as addressing other criticism, in particular she points out that the supply price of capital was incorporated in the MEC. ${ }^{18}$

When it comes to policy, post-Keynesian discourse appears to seek to devise a monetary policy based on an application of post-Keynesian methods of uncertainty and credit. There is a tacit acceptance of the 'Keynesian` position on Keynes's policy, and a failure or even refusal to recognise or accept that Keynes had important views on monetary policy of his own. Rochon (2007) has the modern debate between two rival camps: Those who favour an ractivist approach, involving the use of nominal interest rates as a tool of aggregate demand fine-tuning, and those who prefer to spark « the interest rate according to a specific rule, and manage demand with fiscal policy. Inflation remains a central pre-occupation, as exemplified by the remit for these papers.

Certainly these arguments are better than those of the `Keynesians`. But they scratch the surface of Keynes's monetary theory. With too much emphasis on the discount rate, they fail to acknowledge the broader and more profound distinctions between dear and cheap money and between liberal and managed financial systems; this leads to a severe misinterpretation of the present economic order of the world.

\section{Consequences}

According to the discussion above, economic activity depends on a far broader interpretation of the monetary environment than the approach to discount rate policy alone. Most critical is the level of the long-term real rate of interest: whether money is cheap or dear.

For Keynes, the high interest rates of the I920s were the cause of the Great Depression. We are now in a position to examine the trajectory of real interest rates through the whole of the twentieth century to the present. Figure 4 on the next page has been construct-

I8 Surprisingly there are few challenges to the validity of the OERG analysis, which was hardly sscientific: The conclusions were drawn on the basis of discussions with representatives of large companies, taking place over dinner at college. Kahn's (1952) and Robinson's (1939) early critiques have been ignored. 
ed from statistics of the interest rate on BAA corporate bonds and long-run figures for the gross domestic product deflator. ${ }^{19}$

Figure 4: Long-term interest rates in the US, adjusted for inflation

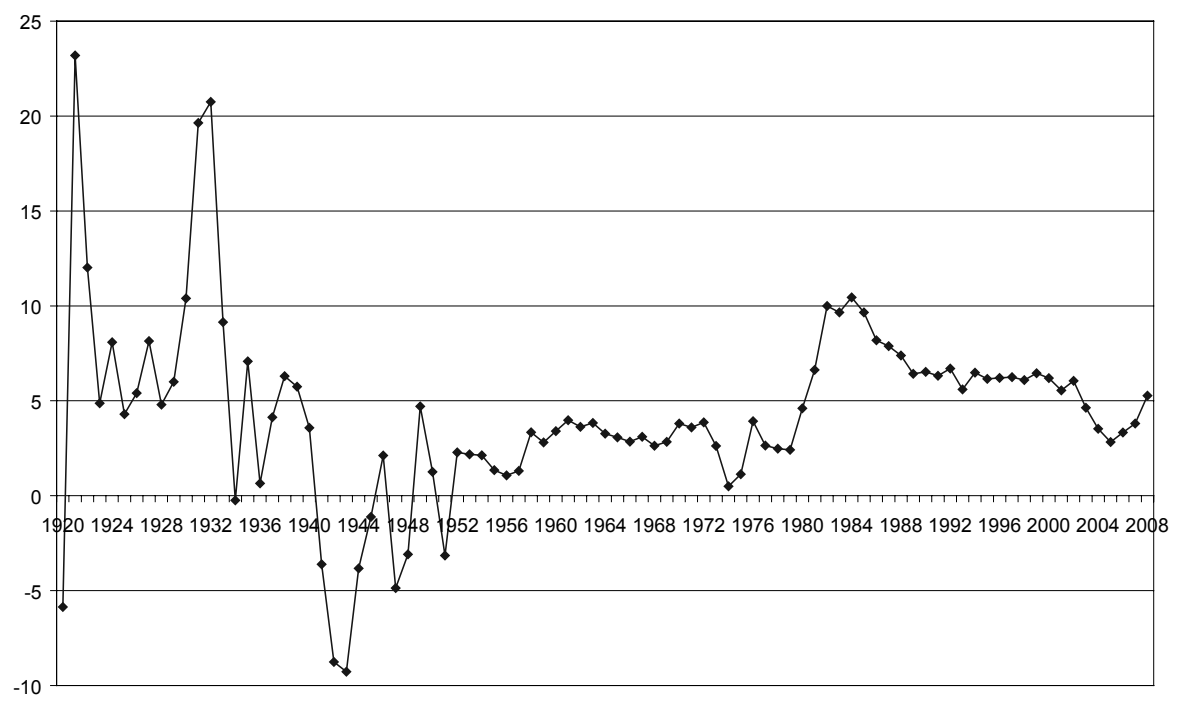

Source: see footnote 19

It seems reasonable to argue that these rates are a guide (if not a lower bound) to the interest rates facing firms across the world. Plainly Keynes's view of the high rates in the I920s is confirmed. Since Keynes's death, financial liberalisation over the period I970 - 80 casts a clear dividing line between an age of cheap money and a modern era of dear money, with, crudely, a doubling in interest. ${ }^{20}$ These broad trends are confirmed by other analyses (see Tily 2007a: Chapter II).

According to this interpretation of the General Theory, the role of cheap money in the golden age must be acknowledged. As is well known, over much of the world unemployment was low and growth high (and the income distribution improved). Fixed capital investment was strong and industrial activity vigorous; the expansion was certainly not due to government expenditure alone. Moreover, as Keynes argued, under cheap money, cyclical forces were subdued, and financial crises were remarkable only by their absence. Price inflation re-

I9 More specifically: interest rates on Moody's BAA corporate bonds from the Federal Reserve website; deflators to 1929 from Friedman (1982) and afterwards from the BEA website.

20 The full story is more subtle, especially the very low interest rates in the I970s (falling negative on government bonds) and the fall of rates at the start of the 2Ist century. These latter reductions appear 
mained relatively subdued. The era surely vindicated Keynes's genius, and has been too easily neglected especially by those who recognise but reject Keynes's monetary policies.

The same analysis should have led to grave concerns about the re-emergence of dear money in the early 1980s. Until 2000, the stability of these high interest rates was remarkable. This stability came in spite of changes in vogue for monetary policy, most notably the switch from monetarism to the new consensus (and also, for some countries, fixing exchange rates).

The performance of the world economy has fallen substantially below that of the golden age. Since 1980, unemployment has increased, growth slowed, and financial instability and the economic cycle have returned. Moreover the period has been characterised - particularly for the US and UK - by almost relentless debt and asset inflations.

In the light of the theory above, these balance sheet inflations should be regarded as symptomatic of excessive expansions. Since 1980, the corporate sector in aggregate has invested at rates of interest that - as in the I920s - simply cannot be afforded. And, over time, an increased burden of debt has been the consequence. Figure 5 on the next page shows a measure of corporate debt for the US. Activity may have retrenched periodically, but the indebtedness grew relentlessly, and indeed has spread to the household and government sectors, let alone its repackaging and concealing as opaque and complex financial instruments and mechanisms probably beyond these figures. The key point is that the US and world economy is leveraged to an extent probably unprecedented in history, with long-term analyses indicating comparability only with the extent of indebtedness as the Great Depression took hold. The extreme indebtedness is the most telling and dangerous symptom of close to thirty years of dear money. Such a state of affairs could never have continued indefinitely.

to be related to responses to the crises starting with the South East-Asia collapse through to the stock exchange crash and subsequent investment falls in the United States in 200I. Central banks around the world reduced discount rates; assets perceived as safer (including highly-rated corporate bonds) became more desirable, leading to increases in price and reductions in interest rates. However, lower interest rates were regarded mainly as an aberration rather than an ongoing condition for future activity. Policymakers and commentators fostered expectations of higher not lower rates into the future, and these higher rates have already become a reality. At the same time there was a vast extension in the supply of money, with the authorities permitting 'financial innovations s such as hedge funds, subprime lending, the carry trade, private equity and various derivatives and credit default and insurance instruments. A working paper in part deals with this issue in more detail (Tily 2008, available on request). 
Figure 5: Total liabilities of US non-financial business, \% net operating surplus

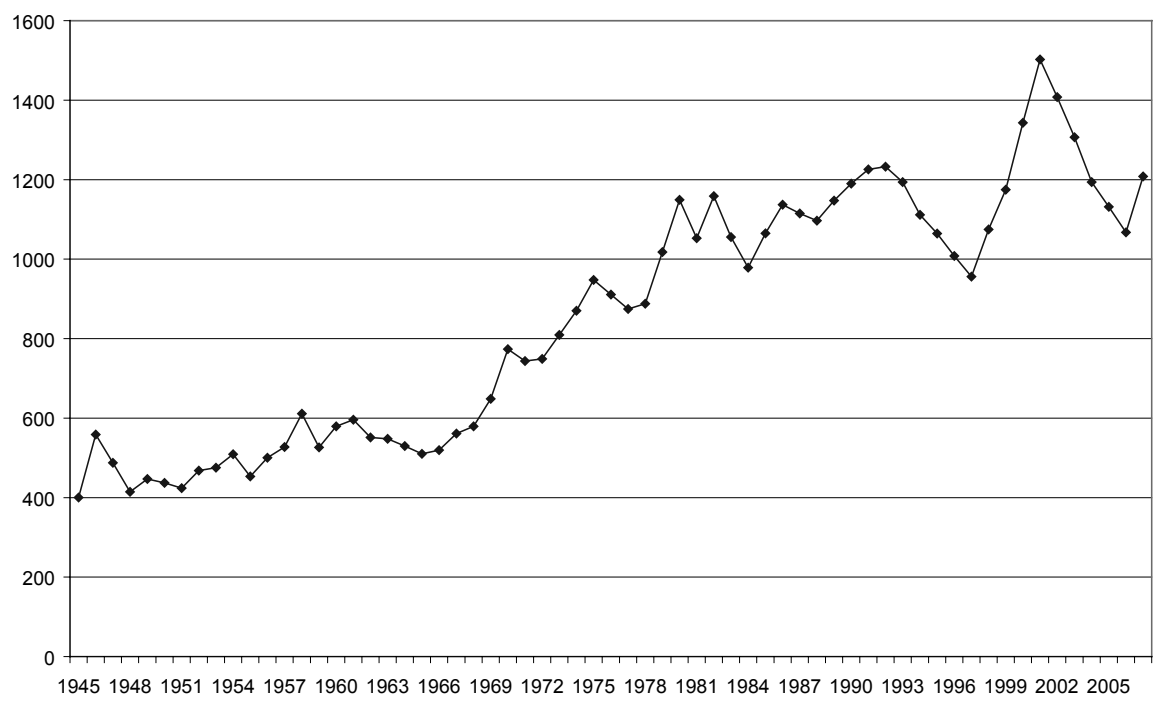

Source: 'Z tablesı, L.101; National Income and Product Accounts, Table 1.14

The ongoing financial market collapse reflects the onset of debt deflation and the beginning of the de-leveraging of the world economy. The increasingly common references to the Great Depression do not seem inappropriate given the unprecedented duration of the modern era of dear money.

\section{Conclusions}

The damage wrought by the `Keynesian` interpretation of the General Theory remains to be fully recognised. Post-Keynesians may have escaped the theoretical nonsense of exogenous money and simultaneous equations, but many appear content with the `Keynesian` interpretation of his policy goals. The extension of post-Keynesianism into the realms of monetary policy seems merely to have bolstered the present policy consensus.

But Keynes's monetary policy is right there in the General Theory, and it is profoundly different to what seem to be the leading post-Keynesian interpretations. The current policy consensus neglects entirely the long rate, and it is that rate that Keynes considered fundamental to the operation of a free market economy. The pre-occupation with inflation exemplifies quite how far from Keynes's doctrines many of his closest followers appear to have strayed. I fear very greatly the consequence of the neglect of this theory and policy that now appears to be unravelling. Perhaps the best to hope for the moment is that the very real crisis might open minds more fully to the General Theory. 


\section{References}

Chick, V. (1983): Macroeconomics after Keynes, Cambridge, Massachusetts: MIT Press.

Chick, V. (1998): Two further essays on equilibrium, UCL Discussion Paper, No. 98(I3).

Chick, V. (200I): Varieties of Post Keynesian monetary theory: Conflicts and (some) resolutions, Paper for the Annual Conference of the Association for Heterodox Economics, July.

Davidson, P. (1978): Money and the Real World (2nd edition), London: Macmillan.

Fisher, I. (1933): The debt-deflation theory of Great Depressions, in: Econometrica, I, $337-357$.

Friedman, M., Schwartz, A.J. (1982): Monetary Trends in the United States and United Kingdom: Their Relation to Income, Prices, and Interest Rates, 1867 - 1975, Chicago and London: University of Chicago Press.

Hayes, M.G. (2008): Review of Tily, G. IKeynes's General Theory, the rate of interest and 'Keynesian economics, in: European Journal of the History of Economic Thought, I5, I5I - I6I.

Henderson, H.D. (1938): The significance of the rate of interest, in: Oxford Economic Papers, I, I - I3.

Kahn, R.F. (1952): Review of `Oxford Studies in the Price Mechanism‘, in: The Economic Journal, 62, $119-130$.

Kahn, R.F. (1975): On Re-reading Keynes, British Academy Lecture.

Kahn, R.F. (1977): Mr. Eltis and the Keynesians, in: Lloyds Bank Review, I24, I - I3.

Kahn, R.F. (1984): The Making of The General Theory, Cambridge: Cambridge University Press.

Kaldor, N. (1972): The irrelevance of equilibrium economics, in: Economic Journal, 82, I237- I255.

Keynes, J.M. (1971 - 1989): The Collected Writings of John Maynard Keynes, 30 volumes, edited by Moggridge, D.E., Johnson, E.S., London: Macmillan and New York: Cambridge University Press, for the Royal Economic Society.

King, J.E. (2002): A History of Post Keynesian Economics Since 1936, Cheltenham: Edward Elgar.

Kregel, J.A.. (1976): Economic methodology in the face of uncertainty: The modelling methods of Keynes and the Post-Keynesians, in: Economic Journal, 86, 209 - 225.

Lerner, A. (1964): The General Theory, in: Lekachman, R. (ed.), Keynes' General Theory: Reports of Three Decades, New York: St Martin's Press.

Meade, J.E., Andrews, P.W.S. (1938): Summary of replies to questions on effects of interest rates, in: Oxford Economic Papers, I, I4-3I.

Minsky, H.P. (1985): The financial instability hypothesis, a restatement, in: Arestis, P. (ed.), Essays in Post Keynesian Economics, Aldershot: Edward Elgar.

Moore, B.J. (2004): Shaking the Invisible Hand: Complexity, Endogenous Money and Exogenous Interest Rates, Basingstoke: Palgrave Macmillan.

Robinson, E.A.G. (1939): Review of R.F. Harrod, H.D. Henderson, J.Marschak \& R. Opie ,Oxford Economic Paperss, in: Economic Journal, 49, 538 - 543. 
Robinson, J.V. (1968): Review of G.L.S. Shackle `The years of high theory: Invention and tradition in economic thought I926 - I939', in: The Philosophical Quarterly, I8, I85- I86.

Rochon, L.P. (2007): The state of Post Keynesian interest rate policy: Where are we and where are we going?, in: Journal of Post Keynesian Economics, 30, 3 - II.

Shackle, G.L.S. (1943): Review of M.F. Timlin `Keynesian Economics`, in: Economica, ıo, $260-262$.

Shackle, G.L.S. (196I): Recent theories concerning the nature and role of interest, in: Economic Journal, 7I, $209-254$.

Shackle, G.L.S. (1965): A Scheme of Economic Theory, Cambridge: Cambridge University Press.

Shackle, G.L.S. (1973): Review of P. Davidson `Money and the Real World`, in: Economic Journal, $83,532-533$.

Tily, G. (2006): Keynes's theory of liquidity preference and his debt management and monetary policies, in: Cambridge Journal of Economics, 30, $657-670$.

Tily, G. (2007a): Keynes's General Theory, the Rate of Interest and ,Keynesian Economics, Basingstoke: Palgrave Macmillan.

Tily, G. (2007b): Keynes, the Post-Keynesians and the curious case of endogenous money, Paper presented at the 2007 conference of the Association for Heterodox Economics.

Tily, G. (2008): What would Keynes do now? Monetary policy and economic depression, Post Keynesian Economics Study Group Working Paper, No. 0802, URL: http://www.postkeynesian.net/members/working papers/Tily I3ı108.pdf

Tily, G. (2009): John Maynard Keynes and the development of National Accounts in Britain, I895 to I94I, in: Review of Income and Wealth, 55, 33I - 359. 